\title{
Decolourisation and Biodegradation of Textile Di-azo Dye Congo Red by Chryseobacterium geocarposphaerae DD3
}

\author{
Shrabana Sarkar ${ }^{1}$, Alex Echeverría-Vega ${ }^{2,3}(\mathbb{D})$, Aparna Banerjee ${ }^{2,3}$ and Rajib Bandopadhyay ${ }^{1, *(\mathbb{D})}$ \\ 1 UGC Center of Advanced Study, Department of Botany, The University of Burdwan, \\ Purba Bardhaman 713104, India; runka.sarkar@gmail.com \\ 2 Centro de Investigación de Estudios Avanzados del Maule, Vicerrectoría de Investigación y Posgrado, \\ Universidad Católica del Maule, Talca 3466706, Chile; aecheverria@ucm.cl (A.E.-V.); abanerjee@ucm.cl (A.B.) \\ 3 Centro de Biotecnología de Los Recursos Naturales (CENBio), Facultad de Ciencias Agrarias y Forestales, \\ Universidad Católica del Maule, Talca 3466706, Chile \\ * Correspondence: rajibindia@gmail.com
}

Citation: Sarkar, S.

Echeverría-Vega, A.; Banerjee, A.; Bandopadhyay, R. Decolourisation and Biodegradation of Textile Di-azo Dye Congo Red by Chryseobacterium geocarposphaerae DD3. Sustainability 2021, 13, 10850. https://doi.org/ $10.3390 /$ su131910850

Academic Editor: Avelino Núñez-Delgado

Received: 19 August 2021

Accepted: 21 September 2021

Published: 29 September 2021

Publisher's Note: MDPI stays neutral with regard to jurisdictional claims in published maps and institutional affiliations.

Copyright: (C) 2021 by the authors Licensee MDPI, Basel, Switzerland. This article is an open access article distributed under the terms and conditions of the Creative Commons Attribution (CC BY) license (https:// creativecommons.org/licenses/by/ $4.0 /)$.
Abstract: In the present study, Chryseobacterium geocarposphaerae DD3 isolated from textile industry dye effluent in West Bengal, India, displayed significant tolerance to sulfonated di-azo dye Congo red (CR), up to $500 \mathrm{ppm}$. The optimum decolourisation revealed that $C$. geocarposphaerae DD3 was capable of $96.52 \%$ decolourisation of $0.2 \mathrm{~g} \mathrm{~L}^{-1} \mathrm{CR}$ within $12 \mathrm{~h}$ of treatment in the presence of $5 \mathrm{~g} \mathrm{~L}^{-1}$ glucose as supplementary carbon source. Biodegradation analysis of decolourised CR containing water was investigated by FTIR, MS and ${ }^{1} \mathrm{H}$ NMR, which confirmed the absence of azo bond as well as the toxic aromatic amines. Further, phytotoxicity analysis was performed to assess the toxicity of CR before and after bacterial treatment. Growth indexes of Vigna radiata L. seed confirmed that the biodegraded water was non-phytotoxic in comparison to the control CR solution. Multivariate analyses confirmed the same, showing significant differences between measured plant health indicators for CR solutions, whereas no significant differences were found between distilled and treated water. This study is novel as it is the first report of dye degradation by C. geocarposphaerae and may lead to a sustainable way of treating dye-contaminated water in the near future.

Keywords: wastewater; textile dye; Congo red; Chryseobacterium; water treatment; decolourisation; biodegradation; phytotoxicity

\section{Introduction}

In today's world, water pollution is an increasingly critical health issue in the context of rising industrialisation and climate change. Access to potable water is becoming rarer and more expensive worldwide. Among the plentiful causes of pollution, a major threat is the textile industry, as it often releases dye-containing effluents into natural water bodies [1]. From an economic viewpoint, although the textile industry plays an important role in any country, it is still an environmental polluter, causing more than $20 \%$ of global water pollution alone [2]. As stated by the World Health Organization (WHO), coloured effluents released after dying treatment by textile industries cause $17-20 \%$ of total water pollution worldwide. It has been found in a case study that $1.65 \mathrm{mg} \mathrm{L}^{-1}$ azo dye released into the Cristais River, São Paulo, Brazil caused a mutagenic effect in humans [3]. It has also been estimated that roughly $10-15 \%$ of the total in azo dyes used globally in textile production are lost through effluent, as they do not bind to textile fibre [4,5]. Approximately 200 billion litres of coloured wastewater are generated every year throughout the world [6]. Environmental legislation mandates that textile factories treat effluents before discharge into receiving water bodies [7]. However, synthetic textile azo dyes are unmanageable and carcinogenic [8] in nature due to the presence of $-\mathrm{N}=\mathrm{N}-$ bonds [9], making them resistant to the impact of detergents, sunshine, temperatures, or other types of degradation [10]. Mainly, electron deficiency is the foremost reason why textile dyes become less susceptible 
to the conventional decolourisation process [11]. Nearly 2 years are required to degrade dye-derived aromatic amines in river and sea sediments [1,12]. Over 10,000 highly water soluble, commercial dye compounds are regularly used in the textile industry to dye fibres [13], causing general environmental concern.

Generally, the dye-containing effluents are intensively coloured and alkaline in $\mathrm{pH}(8.0-11.0)[14,15]$. These types of effluents are also reported to be high in biochemical oxygen demand (BOD), chemical oxygen demand (COD), total suspended solids (TSS) [16], metal contamination [17] due to the presence of dye and additives (like sodium carbonate, caustic soda and other salts) [7] and temperature [18]. In this context of heavy water pollution, recycling wastewater produced by the textile industry is timely and important. Classical remediation approaches based on physical and chemical reactions are expensive and generate secondary pollutants containing amine residues, which are highly carcinogenic and show long-term effects on human as well as aquatic life. Further, chemical degradation processes are so expensive that industries often prefer not to bear that much of the cost [19]. Microbiological treatment is not that over-priced; moreover, it is an environment friendly, sustainable and efficient procedure [20]. Among different biological dye degradation processes [19], microbe-mediated azo dye degradation started back in the 1970 with the isolation of three bacterial strains, namely, Bacillus subtilis, Aeromonas hydrophila and Bacillus cereus [21,22]. Since then, many other bacterial strains have been reported in the field of dye bioremediation. In comparison to conventional processes, bacterial dye degradation is one of the best options for treatment of dye-containing textile effluent. While traditional processes are limited in their chemical and physical processes, environmental bacteria have the capability of rapidly adapting under adverse conditions [23], facilitating growth followed by degradation of dyes in a dye-contaminated environment. Enzymatic networks of bacteria are so well built that they are able to break down the complex chemical structures of synthetic azo dyes to use as essential nutrient sources (carbon and nitrogen sources) for their growth and development [19].

Congo red (CR) has been reported to persist in the environment for a long timethe reason why it is considered as one of the recalcitrant azo dyes. Furthermore, CR is also carcinogenic due to the presence of aromatic amine groups and is used in textile manufacturing. Hence, CR is considered as a model complex pollutant [24]. A few studies have reported on CR biodegradation using different bacteria, including Bacillus $\mathrm{sp}$. ACT1 mediated degradation $(0.05 \% \mathrm{CR})$ in $\sim 30 \mathrm{~h}$ [25], Pseudomonas luteola mediated $95 \%$ degradation efficiency against $0.02 \% \mathrm{CR}$ after $12 \mathrm{~h}$ [26] and Shewanella xiamenensis mediated $87.5 \% \mathrm{CR}$ biodegradation in $16 \mathrm{~h}$ [27].

This study sought to investigate the biodegradation and detoxification of CR using a newly isolated thermotolerant bacterium Chryseobacterium geocarposphaerae DD3 that has not been reported earlier. The mechanism of CR biodegradation and the associated metabolites/by-products were systematically evaluated with FTIR, MS and ${ }^{1} \mathrm{H}$ NMR techniques. C. geocarposphaerae has been reported on earlier for its plant growth promoting activity [28], but this study elaborates a new approach to bioresource utilization in terms of azo dye bioremediation to find potential applications in textile wastewater remediation. To our knowledge, the present study is the first to report on C. geocarposphaerae mediated azo dye biodegradation and detoxification, and is novel in this respect. As this bacterium was isolated from contaminated textile effluent, it was hypothesized to confer elevated tolerance to synthetic azo dyes.

\section{Materials and Methods}

\subsection{Wastewater Collection and Characteristics}

Coloured effluent was collected in sterilized polythene bottle from the dye house outlet of a textile industry operation situated in West Bengal, India (latitude and longitude: $22.73718^{\circ} \mathrm{N}$ and $88.31861^{\circ} \mathrm{E}$, respectively). QGIS 3.1 was used to prepare the map of the study area (Figure 1). Immediately after collection, some physical parameters of the wastewater, e.g., $\mathrm{pH}$, temperature, colour, and smell, were recorded. Within $48 \mathrm{~h}$ of 
collection, the water sample was characterized for total suspended solids (TSS) and total dissolved solids (TDS) using a HORIBA multi-parameter meter (U-50), as well as chemical oxygen demand (COD), biological oxygen demand (BOD), and oil and grease following the standards of APHA (APHA 1999) [29].

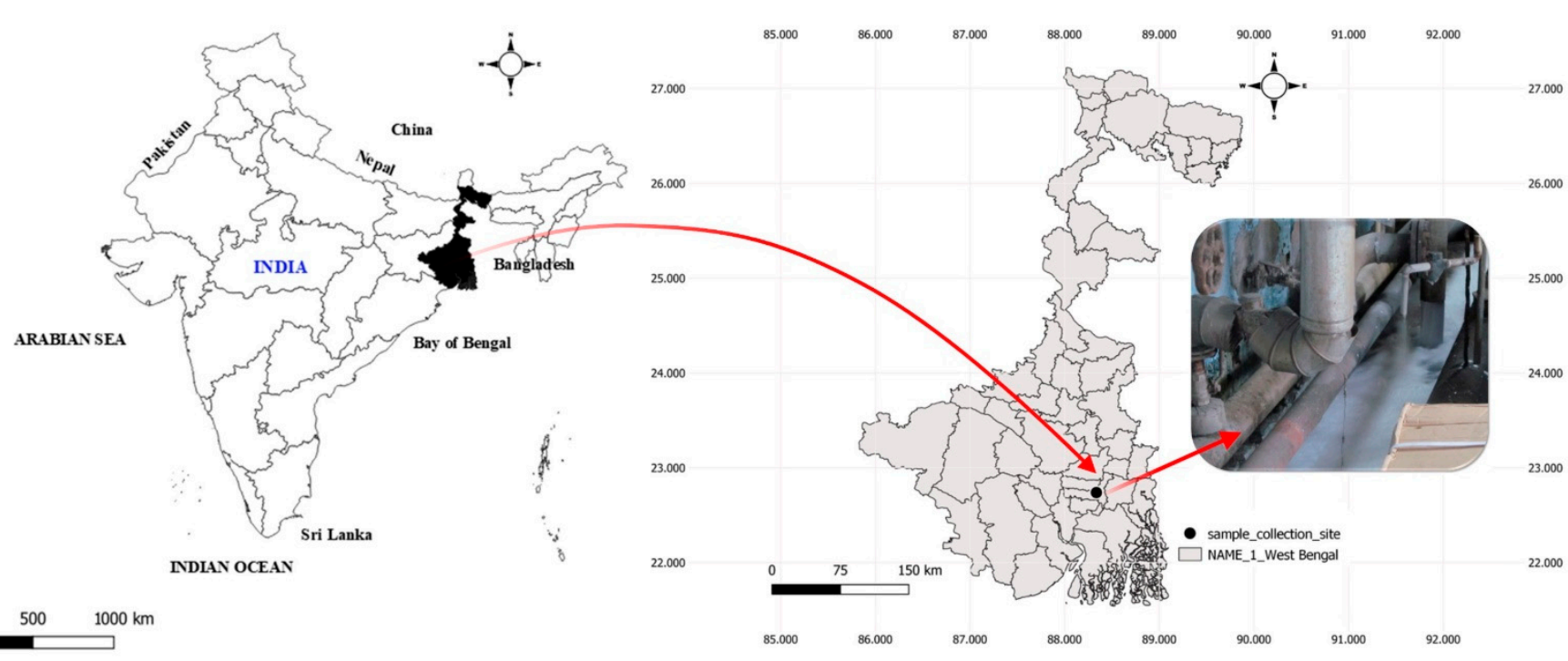

Figure 1. QGIS mapping of study site (Inset: sample collection site).

\subsection{Polyphasic Characterization of the Bacterial Isolate}

\subsubsection{Bacteriological Analysis}

Serially diluted collected coloured water sample was inoculated in modified nutrient agar (NA) medium (without yeast extract, $\mathrm{pH} 7.0$ ) at $37^{\circ} \mathrm{C}$ overnight. Fast growing colonies were isolated to examine their dye tolerance capacity in the modified NA medium supplemented with minimum dye concentration $\left(0.1 \mathrm{~g} \mathrm{~L}^{-1}\right.$ each of Congo red, Malachite green, Brilliant yellow, and Methyl red). Among different bacterial isolates, DD3 demonstrated growth against all the studied azo dyes (best against Congo red) other than Malachite green; thus, DD3 was chosen for further study. The isolate DD3 was primarily classified by Gram staining. Biochemical categorization of DD3 was performed on activity of extracellular enzymes (protease, amylase, catalase, and urease), substrate hydrolysis (cellulose, tributyrin, and olive oil), salt tolerance, $\mathrm{pH}$, citrate and lysine utilization, motility, thermal death point, and antibiotic sensitivity tested using standard protocols [30].

For primary size and shape analysis of DD3, bacterial smear was fixed on a cover glass by $2.5 \%$ glutaraldehyde solution for $30 \mathrm{~min}$ and was dehydrated by passing it through $50-90 \%$ of alcohol for $5 \mathrm{~min}$ in each step. The bacteria on the cover glass were platinum-coated using JEOL JFC 1600 Auto fine coater (Tokyo, Japan) and observed under scanning electron microscope (JEOL JSM-6390, Tokyo, Japan) with 20 KV accelerating voltage. Further detailed morphometric analysis was performed by fixing freshly prepared overnight grown DD3 culture on carbon-coated grid followed by staining with $0.2 \%$ uranyl acetate. Then, the grid was observed under transmission electron microscope (JEM-1011 100 KV TEM, Peabody, MA, USA).

2.2.2. Molecular Characterization by $16 \mathrm{~S}$ rRNA Amplification and Phylogenetic Analysis

Genomic DNA of DD3 was isolated using Zymo Research Fungal/Bacterial DNA MiniPrep (D6005). An approximately $1.5 \mathrm{~kb}$ size $16 \mathrm{~S}$ rRNA fragment was amplified using high fidelity PCR polymerase. The PCR product was sequenced using the universal forward primer (8f) and reverse primer (1492r) with the Sanger sequencing method (Applied Biosystems 3130xl Genetic Analyzer, Foster City, CA, USA). EzTaxon platform was used for identification of the 16S rRNA sequence (http:/ / www.ezbiocloud.net/identify, accessed on 23 May 2020). Evolutionary distances between the sequences were calculated and the phy- 
logenetic tree was prepared by the maximum likelihood method using MEGA (version 7.0). The obtained sequence was deposited at GenBank (accession number MG905828.1).

\subsection{Congo Red Decolourisation Study}

Dye tolerance capacity of DD3 isolate was determined in terms of maximum tolerable concentration (MTC). In this context, mineral salts medium (MSM) was supplemented with $0.1,0.2,0.3,0.4,0.5$, and $0.6 \mathrm{~g} \mathrm{~L}^{-1}$ of $\mathrm{CR}$ (BDH laboratory chemical, UAE) and incubated at $37^{\circ} \mathrm{C}$ for up to $24 \mathrm{~h}$. To analyse the effect of static and agitated conditions (120 rpm) on the decolourisation efficiency of DD3, the bacterial isolate was incubated up to $48 \mathrm{~h}$ in conical flask containing sterile mineral salt media (MSM) with maximum tolerable CR concentration $\left(0.2 \mathrm{~g} \mathrm{~L}^{-1}\right)$. Similarly, the optimum temperature for DD3 mediated CR decolourisation was evaluated at $25,30,35,37,40$, and $45^{\circ} \mathrm{C}$, respectively. Likewise, the effects of varying nutrient sources $\left(1 \mathrm{~g} \mathrm{~L}^{-1}\right)$ (glucose and peptone as carbon source; yeast extract and beef extract as nitrogen source) were also investigated in $0.02 \%$ CR supplemented MSM. The effects of different concentrations of glucose $\left(1-5 \mathrm{~g} \mathrm{~L}^{-1}\right)$ on DD3 mediated dye decolourisation were studied, too. For the decolourisation and biodegradation study, $0.2 \mathrm{~mL}$ freshly cultured inoculum $\left(1.2 \times 10^{5} \mathrm{cfu} / \mathrm{mL}\right)$ was used for $100 \mathrm{~mL}$ media: i.e., inoculum: solution $(v / v)=1: 500$. For all the decolourisation experiments, bacteria cultured without the presence of dye and CR containing MSM incubated without bacterial inoculum were considered as biotic and abiotic controls, respectively. Cell-free supernatant was collected by centrifugation (10,000 rpm for $15 \mathrm{~min})$, and absorbance of the supernatant was measured at predetermined absorbance maxima $(\lambda \max ), 498 \mathrm{~nm}$ for $\mathrm{CR}$ using UV-visible spectrometer (Microprocessor Visible spectrophotometer, Model: LI-721). Percentage of decolourisation was calculated from the difference between initial (before incubation) and final (after growth) absorbance values. The best optimized condition for the decolourisation was considered for the further experiments.

To calculate decolourisation percentage the following equations was considered:

$$
\% \text { of decolourisation : } \frac{\text { Initial } O D-\text { Final } O D}{\text { Initial } O D} \times 100
$$

The statistical analysis was performed using the SAS University Edition software. One-way non-parametric analysis of variance (Kruskal-Wallis test) was used to find the significance of the treatments in the final \% of decolourisation of the solutions. The comparisons among treatment levels were made with Tukey's multiple comparison test. Chi-square statistic was used to test the hypothesis.

\subsection{Analysis of Biodegradation Using Different Spectroscopic Methods}

For Fourier transform infrared (FTIR) spectroscopic analysis, overnight-incubated DD3 culture was centrifuged $(10,000 \mathrm{rpm}$ for $15 \mathrm{~min})$, and cell free supernatant was collected separately for the further experiments. FTIR was performed for the control ( $0.02 \%$ aqueous CR solution) and sample (metabolites / by-products produced after bacterial decolourisation). The scan was performed in the mid-IR region of $400-4000 \mathrm{~cm}^{-1}$ with two scan repeats using Perkin Elmer, UATR Two Series spectrophotometer. Peaks were analysed through OriginPro8 software. For sample extraction to perform proton nuclear magnetic resonance $\left({ }^{1} \mathrm{H}\right.$ NMR) spectroscopy, centrifuged $\left(15 \mathrm{~min}\right.$ at $10,000 \mathrm{rpm}$ at $\left.4{ }^{\circ} \mathrm{C}\right)$ cellfree supernatant was vortexed thoroughly with an equal volume of ethyl acetate $(v / v, 1: 1)$. The organic layer was parted and further collected by separating funnel and air-dried at room temperature $\left(35^{\circ} \mathrm{C}\right)$. The collected $5-7 \mathrm{mg}$ of metabolite powder was mixed with $0.5 \mathrm{~mL}$ deuterated solvent and analysed by ${ }^{1} \mathrm{H}$ NMR-300 MHZ (Bruker, Billerica, MA, USA). For mass spectrometric (MS) analysis, a millimolar concentration of the powdered by-product mixed with spectroscopic grade methanol was used. 


\subsection{Phytotoxicity Study}

This experiment was performed by following the method described before by Rana et al. [31] with little modification. Seeds of Vigna radiata (L.) R. Wilkzek (mung bean) were obtained from Indian Agricultural Research Institute, PUSA, New Delhi. After washing, the healthy and uniform seeds were washed with distilled water thoroughly. Then, surface sterilisation of those seeds was performed using $0.1 \% \mathrm{HgCl}_{2}$ treatment, followed by rinsing 6 times with distilled water. For pre-germination treatment, seeds were soaked in 3 different conditions ( 3 experimental sets) for $6 \mathrm{~h}$ at $30^{\circ} \mathrm{C}$; set 1: Control (autoclaved, double distilled water), set 2: CR solution ( $0.02 \%$ aqueous CR) and set 3: DD3 treated wastewater (bacteria decolourised water). Ten seeds were placed on soaked filter paper in Petri plates. For germination purposes, the seeds were irrigated with equal volumes of autoclaved doubled distilled water. Initially, after $48 \mathrm{~h}$, the number of germinated seedlings from each plate was counted and divided by the total number of seeds (10) to calculate the germination rate. At the end of the experiment (7 days), other seed growth parameters such as length of root and shoot and number, length, and width of leaves were recorded. For the assessment of phytotoxicity, the following equations were considered:

$$
\begin{gathered}
\text { Relative germination }=\frac{\text { number of gemination in test }}{\text { number of gemination in control }} \times 100 \\
\% \text { of toxicity }=\left[\frac{\{(\text { radicle length of control }- \text { radicle length of test })\}}{\text { radicle length of control }}\right] \\
\text { Tolerance index }=\frac{\text { Mean length of longest root in tratment }}{\text { Mean length of longest root in control }} \\
\text { Vigour index }=\begin{array}{l}
\{(\text { mean root length }+ \text { mean shoot length })\} \\
\times \% \text { of germination }
\end{array}
\end{gathered}
$$

This experiment was performed in triplicate for each experimental set. Permutational multivariate analysis of variance (PERMANOVA) test with 10,000 permutations was performed using Primer6 (PrimerE) software to determine differences between the treatments. Principal component analysis (PCA) was conducted on 3 kinds of treatments (distilled water, $0.2 \% \mathrm{CR}$, and bacteria mediated biodegraded CR). Varimax rotation was applied as orthogonal rotation minimizes the number of variables with high loading on each component to facilitate interpretation of the results. Statistical significance was defined as $p<0.05$.

\section{Results}

\subsection{Wastewater Collection and Characteristics}

The waste effluent was dark greyish blue in colour with temperature of $55^{\circ} \mathrm{C}$ and $\mathrm{pH}$ of 8.91. The high COD (4337.34 $\left.\mathrm{mgO}_{2} \mathrm{~L}^{-1}\right), \mathrm{BOD}(607 \mathrm{ppm})$, TSS (223 ppm), TDS (332 ppm) and oil-grease $\left(6.32 \mathrm{mg} \mathrm{L}^{-1}\right)$ were recorded for the collected effluent sample (see Supplementary Materials, Table S1).

\subsection{Polyphasic Characterisation and Identification of Chryseobacterium geocarposphaerae DD3}

Based on the considerable initial tolerance of $\mathrm{CR}$ among the other studied dyes to DD3, this isolate was chosen for further CR decolourisation study. The DD3 isolate was Gram-negative, non-endospore forming, high-temperature tolerant (up to $95^{\circ} \mathrm{C}$ ), slightly halophilic (up to $3 \%$ salt $/ \mathrm{NaCl}$ tolerant), alkaliphilic (growth until $\mathrm{pH} 12.0$ ), aerobic, and motile in nature (see Supplementary Materials, Table S2). It was catalase-positive and was able to hydrolyse different substrates such as tributyrin and casein. Other than this, it also used lysine as an important substrate for growth. It was able to ferment citrate, D-fructose, and D-glucose, as carbon sources for growth. The bacterial isolate showed susceptibility against all the studied antibiotics (polymyxin-B, streptomycin, norfloxacin, penicillin-G, 
amoxicillin, chloramphenicol, ampicillin, cefotamine, ceftriaxone, mezlocillin) except the antifungal fluconazole.

16S rRNA sequencing analysis using an EZ-Taxon server revealed that isolated DD3 had 99.36\% nucleotide identity with Chryseobacterium geocarposphaerae 91A-561. Other than this, six different Chryseobacterium species also exhibited more than $97 \%$ similarity with DD3 (Figure 2). Thus, based on the results of 16S rRNA analysis, DD3 was identified as Chryseobacterium geocarposphaerae. The electron micrographs confirmed that the bacteria C. geocarposphaerae DD3 are coccobacilli in shape (Figure 2). In transmission electron micrographs, the presence of outer membrane confirmed the Gram-negative nature of the bacterium.

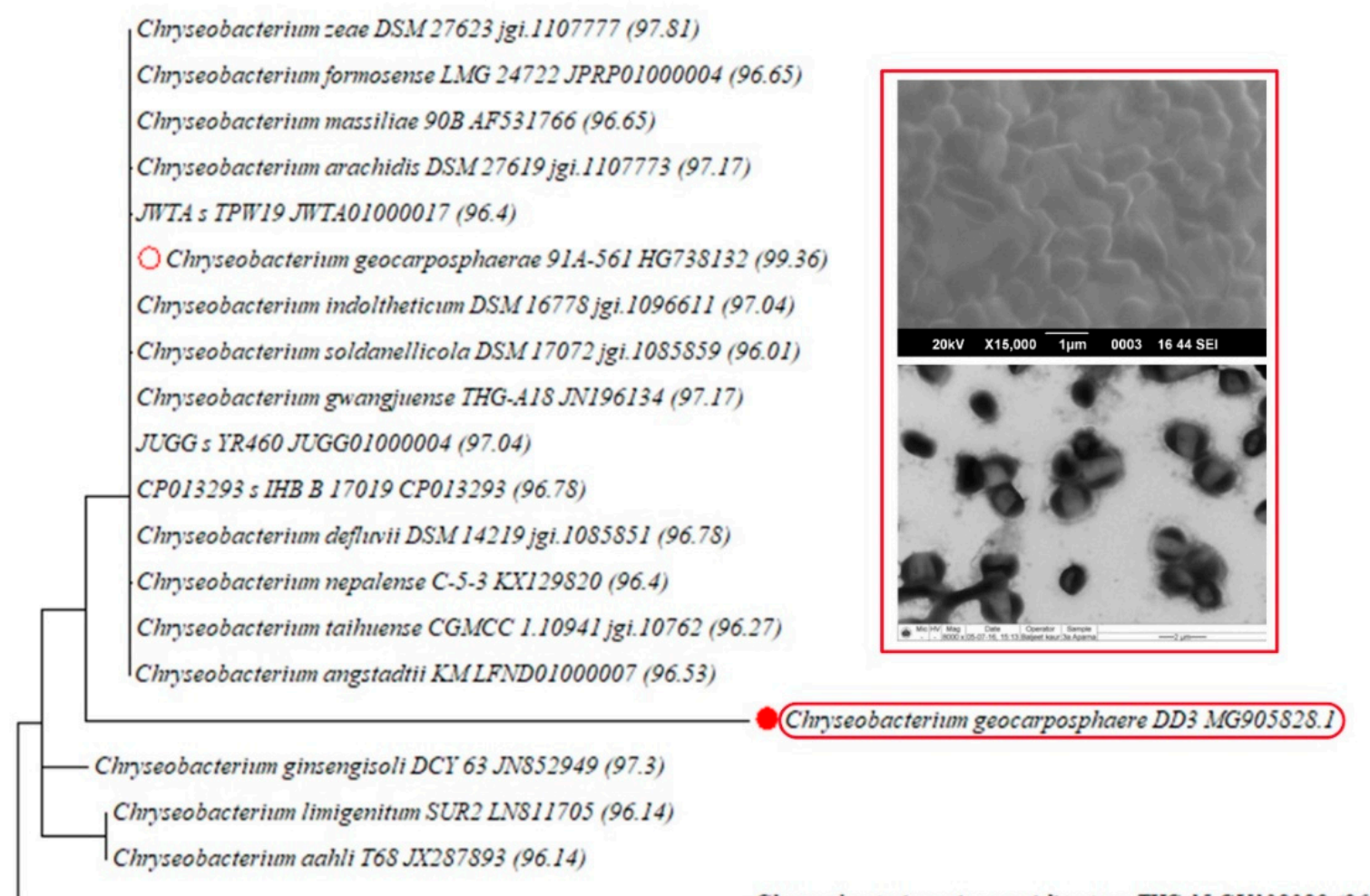

Chyseobacterium ginsenosidimutans THG 15 GU138380 (96.78)

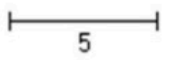

Figure 2. Phylogenetic tree of Chryseobacterium geocarposphaerae DD3 (Inset: scanning electron micrograph and transmission electron micrograph of C. geocarposphaerae DD3 representing its shape and structural characteristics).

\subsection{Congo Red Decolourisation Study}

Upon treating C. geocarposphaerae DD3 with increasing concentrations of $\mathrm{CR}$, the bacteria showed MTC at the concentration of $0.5 \mathrm{~g} \mathrm{~L}^{-1}$. Therefore, the bacterium showed tolerance up to $500 \mathrm{ppm} \mathrm{CR}$ concentration. The initial rate of dye decolourisation was more than $90 \%$ at $12 \mathrm{~h}$ of incubation, irrespective of various concentrations of CR used for the study (Figure 3A). C. geocarposphaerae DD3 mediated optimum decolourisation was $97.58 \%$ in the presence of $0.02 \% \mathrm{CR}$ after $12 \mathrm{~h}$. Beyond this concentration, \% of decolourisation was found to be decreased with increasing initial dye concentration. Decolourisation by C. geocarposphaerae DD3 was studied under both static and agitated conditions (120 rpm) with $0.02 \%$ dye concentration. Maximal decolourisation was observed at $97 \%$ in the presence of agitation after $48 \mathrm{~h}$ of incubation. Therefore, agitation was adapted for further studies. Among a range of studied temperatures $\left(30-45^{\circ} \mathrm{C}\right)$, the highest percentage $(96.5 \%)$ of decolourisation was found at $37^{\circ} \mathrm{C}$ for $\mathrm{C}$. geocarposphaerae DD3 mediated CR decolourisation (Figure 3B). Figure 3C shows that C. geocarposphaerae DD3 mediated CR decolourisation was influenced by all the studied nitrogen and carbon sources to an extent, whereas yeast 
extract (nitrogen source) and glucose (carbon source) elevated (70.09\% for yeast extract and $96.34 \%$ for glucose) the decolourisation response. On varying the concentration of glucose as additional carbon source, the \% of decolourisation increased with increasing glucose concentration, and the highest decolourisation (97.96\%) was observed in the presence of $5 \mathrm{~g} \mathrm{~L}^{-1}$ glucose for CR supplemented $(0.02 \%)$ media at $12 \mathrm{~h}$. Statistical analysis showed significance for both the factors medium used for reaction and reaction time with a $p$-value 0.0041 and 0.0417, respectively (see Supplementary Materials, Figure S1). Hence, based on the paired tests between the conditions, the statistically significant experimental condition was further used for the biodegradation analysis and toxicity assessment study.
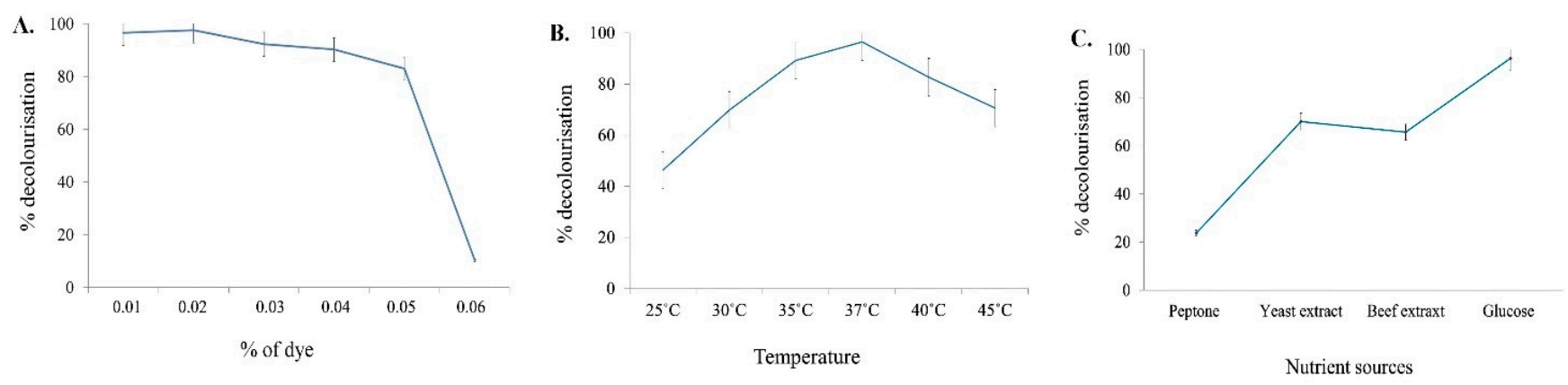

Figure 3. Study of CR decolourisation by C. geocarposphaerae DD3: (A) Effect of different percentages of CR dye; (B) effect of temperature $\left({ }^{\circ} \mathrm{C}\right)$; (C) effect of different nutrient sources (nitrogen source and carbon source) on \% of decolourisation.

\subsection{Analysis of Biodegradation Using Different Spectroscopic Methods}

Incubation with C. geocarposphaerae DD3 successfully resulted in decolourisation of $\mathrm{CR}$. The bio-transformed metabolites related to the decolourisation were characterised by FTIR, MS, and ${ }^{1} \mathrm{H}$ NMR. The result of FTIR analysis of the CR sample and decolourised water showed differences in various peaks, indicating the change/presence of various functional groups. The result of FTIR analysis of the control CR sample showed peaks in the regions of $645 \mathrm{~cm}^{-1}$ (C-C bending vibration of aromatic rings), $1446 \mathrm{~cm}^{-1}$ (aromatic $C=C$ stretching vibration), $1520.63 \mathrm{~cm}^{-1}(C=C$ stretching vibration in benzene ring), $1584 \mathrm{~cm}^{-1}$ (-N=N- azo bond stretching vibration), $1740 \mathrm{~cm}^{-1}$ (-C=O stretching vibration), and $1450-1200 \mathrm{~cm}^{-1}$ (phenolic $\mathrm{C}-\mathrm{O}$ stretch vibration). In the FTIR spectrum of metabolites obtained after decolourisation of CR by C. geocarposphaerae DD3, the disappearance of the peak at $1584 \mathrm{~cm}^{-1}$ for $-\mathrm{N}=\mathrm{N}$ - stretching vibration hinted at the reductive cleavage of azo bond of CR; the disappearance of functional groups at $1450-1200 \mathrm{~cm}^{-1}$ for phenol $\mathrm{C}-\mathrm{O}$ stretching vibration indicated biodegradation of $\mathrm{CR}$; and absence of vibrated stretch within $645-831 \mathrm{~cm}^{-1}$ indicated absence of carcinogenic aromatic amine in the treated water sample (Figure 4A). The MS analysis of the studied sample indicated similar results (Figure 4B). By analysing the $\mathrm{m} / \mathrm{z}$ spectra, a few intermediates, namely, sodium 4-amino-3(phenyldiazenyl) naphthalene-2-sulfonate ( $\mathrm{m} / \mathrm{z}$ 324.2721), sodium 3,4-diaminonapthalene2-sulfonate $(\mathrm{m} / \mathrm{z} 260)$, and aniline $(\mathrm{m} / \mathrm{z} 99.08)$ followed by toluene $(\mathrm{m} / \mathrm{z} 92.00)$ were identified. ${ }^{1} \mathrm{H}$ NMR peaks of the treated water sample appeared at $\delta-1.5 \mathrm{ppm}\left(-\mathrm{R}_{3} \mathrm{CH}\right)$, indicating conversion of the aromatic component to an aliphatic one [32]. The absence of ${ }^{1} \mathrm{H}$ NMR peaks at $\delta-7.5(\mathrm{Ar}-\mathrm{H})$ (Figure 5) in our study clearly indicated the absence of the carcinogenic aromatic amine in bacteria-treated aqueous CR solution [33]. Peaks in $\delta-6.6-8.0$ are reported to be attributable to the presence of aromatic protons [32]. The absence of this stretch in this study indicated the degradation of CR without forming any carcinogenic amine as by-product (Figure 5). The peak in $\delta-2.3 \mathrm{ppm}$ indicated the presence of the relatively non-toxic end-product toluene in the treated water. 


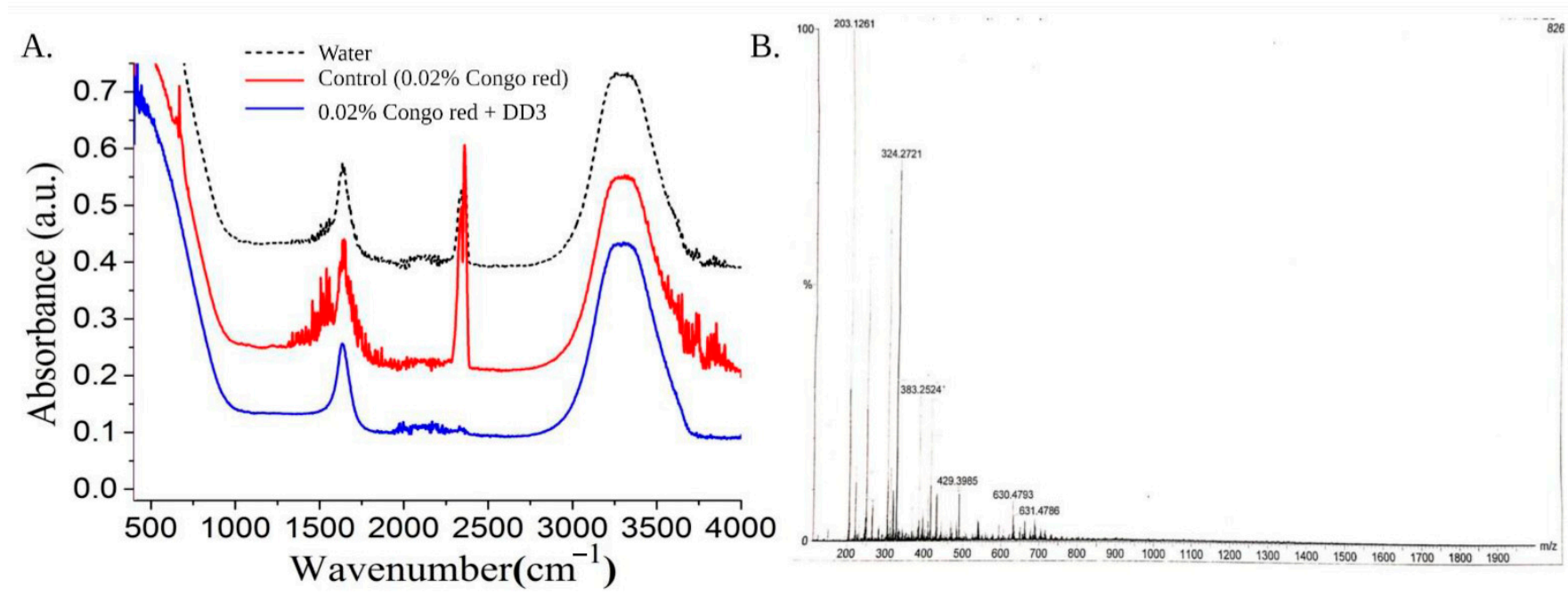

Figure 4. C. geocarposphaerae DD3 mediated biodegradation analysis: (A) FTIR of untreated and treated dye containing water sample represents the breakdown of chemical structure of $C R ;(B)$ mass spectrometry of bacteria treated water sample to identify the $\mathrm{m} / \mathrm{z}$ ratios of intermediates produced after the treatment.
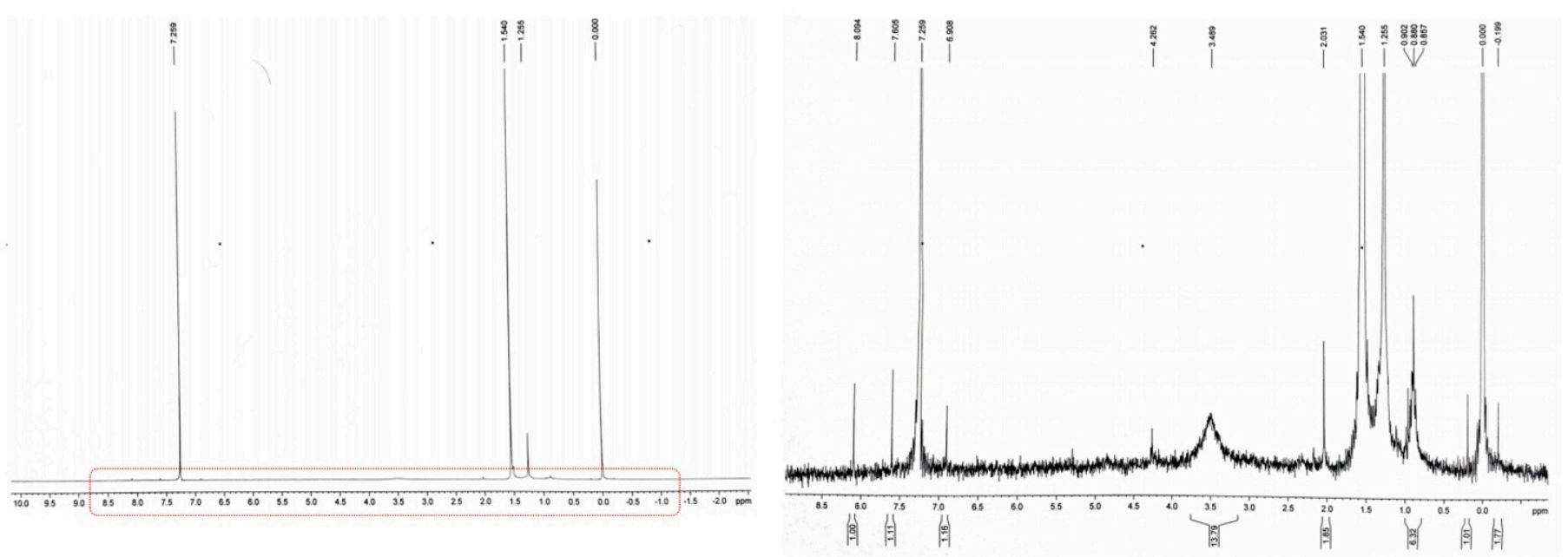

Figure 5. ${ }^{1} \mathrm{H}$ NMR spectroscopy of $C$. geocarposphaerae DD3 treated water sample.

By analysing ${ }^{1} \mathrm{H}$ NMR spectra and $\mathrm{m} / \mathrm{z}$ values from MS spectrometry, probable intermediates formed after CR biodegradation were identified, and the biodegradation pathway was predicted by means of chemistry (Figure 6).

\subsection{Phytotoxicity Study}

The phytotoxicity of $\mathrm{CR}$ before and after $C$. geocarposphaerae DD3 mediated biodegradation was studied. Figure 7A,B shows germinated seedlings pre-treated with DD3-treated water and CR solution, respectively. Figure $7 C$ shows a comparison of seedling growth (in CR solution, C. geocarposphaerae DD3 treated water, and control, i.e., distilled water). 


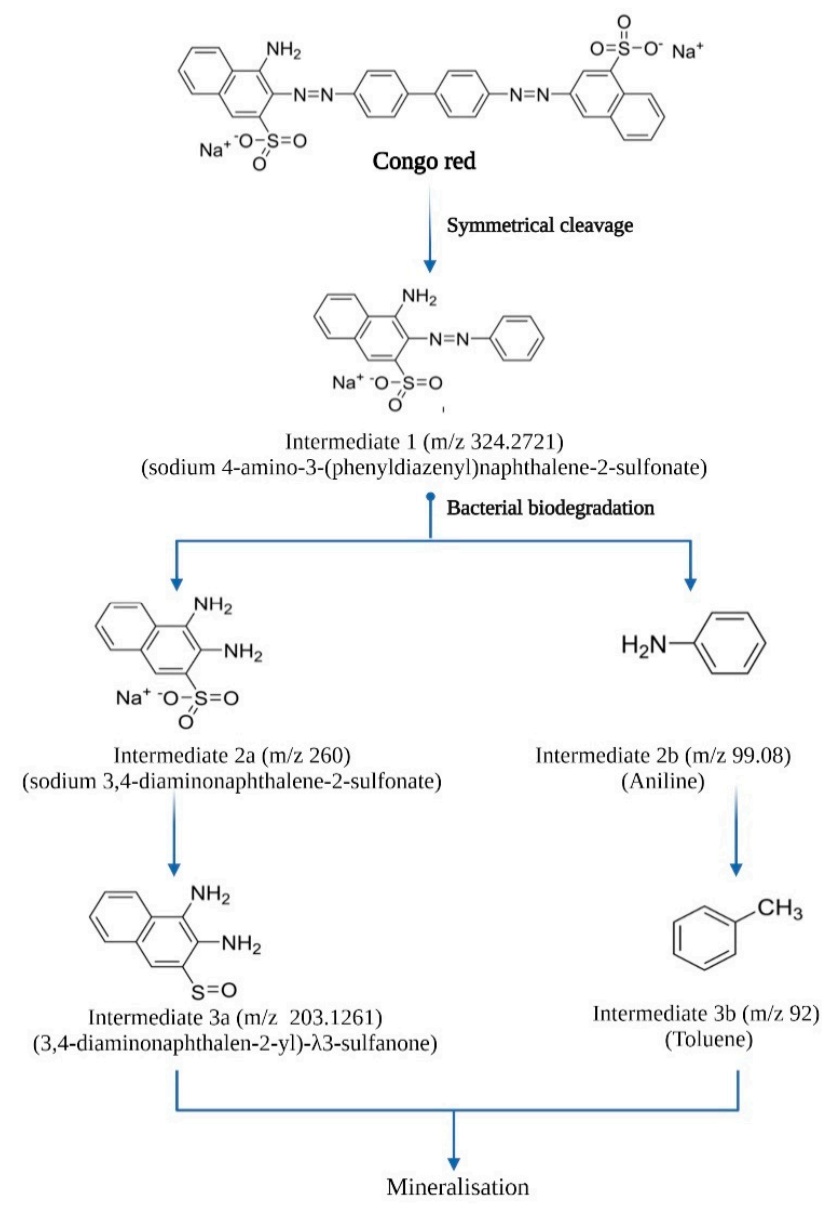

Figure 6. Prediction of CR biodegradation pathway during treatment with C. geocarposphaerae DD3.

A.

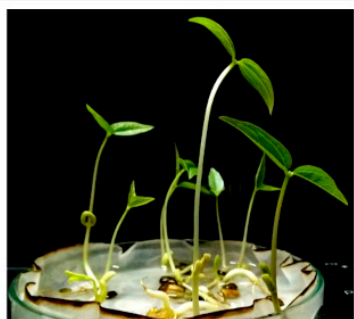

B.

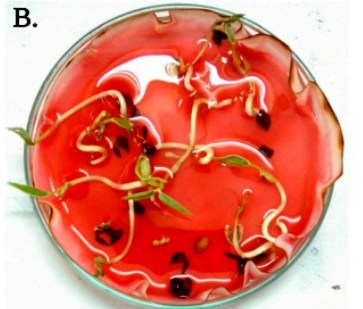

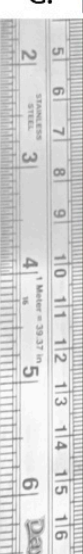

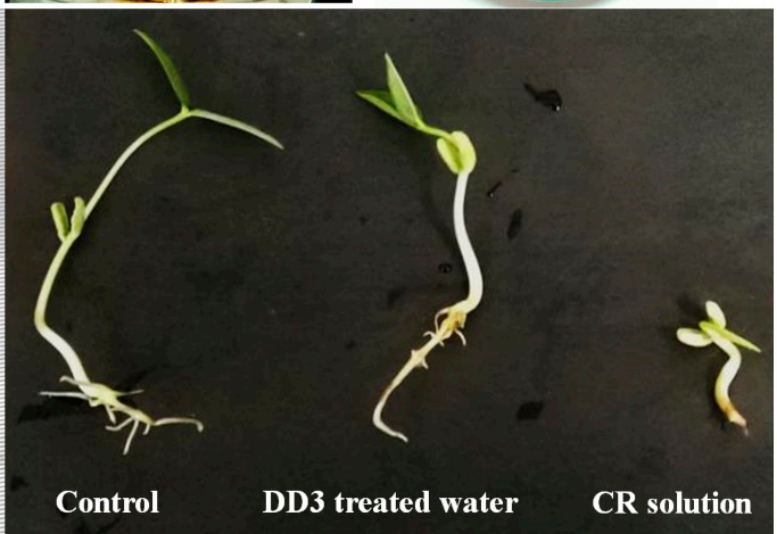

Figure 7. Phytotoxicity assessment of CR on Vigna radiata (L.) R. Wilkzek (mung bean) by germination of seeds pre-treated with (A) DD3 treated water (bacteria decolourised water) and (B) CR solution $(0.02 \%$ CR aqueous CR); (C) Comparison of growth of seedlings (control, DD3 treated water, and CR solution). 
Out of all the parameters measured in relation to the phytotoxicity assessment, three parameters, namely, the germination rate, \% toxicity, and vigour index, showed significant differences in the treatment with CR solution compared to DD3-treated water and control (Table 1). The detailed plant growth indexes measured to assess the phytotoxicity of $\mathrm{CR}$ are listed in Table 1.

Table 1. Phytotoxicity assessment of CR solution and C. geocarposphaerae treated water sample in comparison to the control.

\begin{tabular}{cccc}
\hline Characteristics & Control & DD3 Treated Water & CR Solution \\
\hline Plumule length & $3 \mathrm{~cm}$ & $1.9 \mathrm{~cm}$ & - \\
Radicle length & $5.6 \mathrm{~cm}$ & $5.4 \mathrm{~cm}$ & - \\
Root length & $2.4 \mathrm{~cm}$ & $3.4 \mathrm{~cm}$ & $1.1 \mathrm{~cm}$ \\
Number of roots & 9 & 11 & 2 \\
Shoot length & $6.0 \mathrm{~cm}$ & $4.4 \mathrm{~cm}$ & $1.3 \mathrm{~cm}$ \\
Number of leaves & 2 & 2 & - \\
Length of leaf & $1.9 \mathrm{~cm}$ & $1.5 \mathrm{~cm}$ & - \\
Width of leaf & $0.8 \mathrm{~cm}$ & $0.8 \mathrm{~cm}$ & - \\
Germination rate & $90 \%$ & $80 \%$ & $50 \%$ \\
Relative germination & $100 \%$ & $88.89 \%$ & $55.56 \%$ \\
\% toxicity & $0 \%$ & $3.57 \%$ & $100 \%$ \\
Tolerance index & - & 1.41 & 0.45 \\
Vigour index & 756 & 624 & 120 \\
\hline
\end{tabular}

"-" signifies no growth, control denotes autoclaved double dist. water; DD3 treated water denotes bacteria decolourised water and CR solution denotes $0.02 \%$ aqueous CR solution.

From individual variable analysis, based on correlations, four groups of variables (group 1: tolerance index and root length; group 2: \% toxicity, number of leaves, radicle length, and width of leaves; group 3: vigour index and shoot length; group 4: relative germination and germination rate) showed strong correlations (98\%) with each other (Figure 8A). The selection was made based on correlation analysis. Multivariate analysis with PERMANOVA test was performed with the variables germination rate, plumule length, root length, number of roots, shoot length, and number and length of leaves. Significant differences were found between the different treatments $(p<0.0033)$. A principal components analysis (PCA) was performed (Figure $8 \mathrm{~B}$ ), showing $96 \%$ of total data variance explained by two principal components (PC) (PC1 was 90.9\% and PC2 was 6.5\%). Figure 8B shows loading of PC1 versus PC2. The relationship of CR contamination to seed germination was clearly observed as discussed before by You et al. (2019) [34]. Highest positive loading of $\mathrm{PC} 1$ was on $0.02 \% \mathrm{CR}$ solution, indicating their variations may follow similar trends along with negative loading of number and length of root, which is a key index for CR contamination on seed germination. All plant germination indexes were focused on second and third quadrants, reflecting contamination with different sensitivities. The samples corresponding to the control (distilled water) and treated water showed non-significant difference, i.e., samples treated with $\mathrm{CR}$ showed nearly the same growth indexes as the control. 

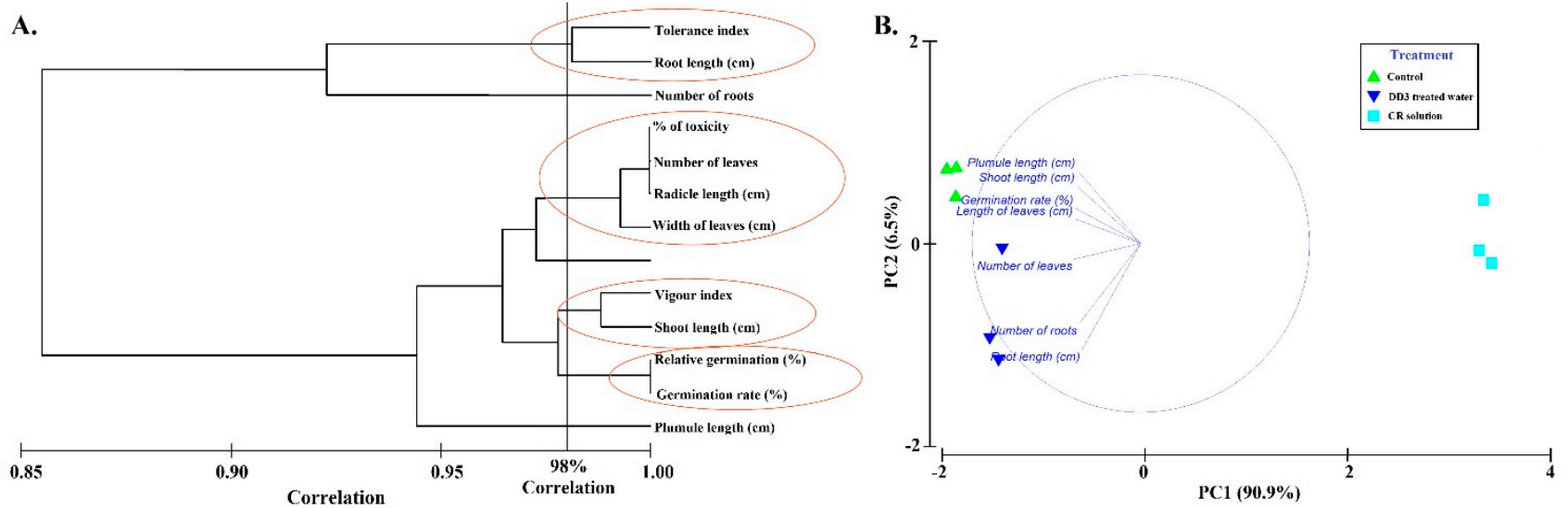

Figure 8. Multivariate analysis. (A) Variable Pearson correlations where red circles indicate groups of over $98 \%$ correlation, with significant differences between the different treatments $(p<0.0033)$; (B) Principal component analysis results, loading plot PC1 vs. PC2 showing $96 \%$ total data variance.

\section{Discussion}

The dye $\mathrm{CR}$ seemed to be toxic to the bacterium C. geocarposphaerae DD3 above a certain concentration, as no growth was recorded after the maximum tolerable concentration. A similar study of di-azo dye (Navitan Fast Blue) was performed previously by Nachiyar and Rajkumar [35] for Pseudomonas aeruginosa, which could degrade (90\%) $100 \mathrm{mg} \mathrm{L}^{-1}$ Navitan Fast Blue S54, in $24 \mathrm{~h}$ with an MTC of $1200 \mathrm{mg} \mathrm{L}^{-1}$; however, concentrations above this level caused acute toxicity. Better decolourisation was observed under controlled agitation, as agitation probably dominates bacterial respiration [10] and helps to utilise NADH as a cofactor to decolourise the azo dyes [36]. A similar experiment performed with $P$. aeruginosa showed better dye degradation $(0.01 \%$ dye concentration) under continuous agitation ( $90 \%$ degradation in $48 \mathrm{~h}$ ) than static incubation ( $80 \%$ in $48 \mathrm{~h}$ ), thus supporting our findings [35]. The optimum decolourisation was found at $37^{\circ} \mathrm{C}$, but DD3 also demonstrated decolourisation capacity at $45^{\circ} \mathrm{C}$, which demonstrates the thermotolerant nature of the bacterium. A similar observation was previously reported by Kolekar et al. [36] on the effect of temperature $\left(20-45^{\circ} \mathrm{C}\right)$ for Bacillus fusiformis mediated disperse blue 79 and acid orange 10 degradation. Another study reported the effect of temperature $\left(10-60{ }^{\circ} \mathrm{C}\right.$, in $10{ }^{\circ} \mathrm{C}$ increments) on CR decolourisation $\left(94.52 \%\right.$ of $0.01 \% \mathrm{CR}$ at $32 \pm 2{ }^{\circ} \mathrm{C}$ ) [37]. According to several earlier reports [38-40], the addition of carbon and nitrogen sources increases decolourisation efficiency. As observed from this study, yeast extract (nitrogen source) and glucose (carbon source) positively influenced C. geocarposphaerae DD3 mediated CR decolourisation. Yeast extract as nitrogen source is probably essential for the regeneration of $\mathrm{NADH}$, an electron donor that helps the microorganism to reduce the azo bond in the chemical structure of azo dye [40]. On the other hand, at the initial stage of growth, the presence of a ready carbon source (glucose) helps to produce secondary metabolites, extracellular enzymes, which in turn may influence the azo dye decolourisation [38]. According to a report by Singh et al. [41] on the effect of external nitrogen and carbon sources, Staphylococcus hominis RMLRT03 showed elevated decolourisation (89.81\% and $93.24 \%$, respectively) in the presence of glucose and yeast extract. On the contrary, in our study, C. geocarposphaerae DD3 showed better decolourisation only in the presence of glucose as a carbon source. It was clearly observed that DD3 can decolourise $0.02 \% \mathrm{CR}$ with more proficiency $\left(96.52 \%\right.$ in $12 \mathrm{~h}$ for the media supplemented with $5 \mathrm{~g} \mathrm{~L}^{-1}$ glucose at $37^{\circ} \mathrm{C}$ ) and an adsorption efficiency of $66.63 \mathrm{mg} / \mathrm{g}$ bacterial cell. Sari et al. [42] previously described the adsorption efficiency determination. Overall, C. geocarposphaerae DD3 had better decolourisation efficiency than previously reported in CR decolourisation studies for Shewanella xiamenensis BC01 (87.5\% decolourisation of $0.02 \%$ dye in $16 \mathrm{~h}$ ) [27], Bacillus sp. $(0.01 \%$ dye after $50 \mathrm{~h}$ ) [25,27], or Bacillus cohnni RKS9 (99\% degradation in $12 \mathrm{~h}$ for $0.01 \%$ dye) [43]. Mutant Bacillus sp. ACT1 (using UV and Ethidium bromide) showed 0.05\% 
degradation ability after a long time interval of $\sim 30 \mathrm{~h}$ [25], whereas our isolate of interest took much less time, only $12 \mathrm{~h}$ without any strain mutation.

Bacteria isolated from dye-contaminated sites can process the bioremediation of azo dye, which is a clear indication of environmental adaptation to toxic synthetic dye [36]. In the present study, CR biodegradation was confirmed by FTIR, MS (Figure 4), and ${ }^{1} \mathrm{H}$ NMR analysis (Figure 5). Previously, the CR biodegradation pathway was studied mostly using mixed bacterial cultures [32] or fungal cultures [44], whereas comparatively little study had been pursued on monoculture-based CR degradation [45]. In this study, mainly ${ }^{1} \mathrm{H}$ NMR spectra and $\mathrm{m} / \mathrm{z}$ values of intermediates (received from MS study in Figure 4B) were analysed to hypothesise a CR degradation pathway supported by FTIR. In our study, according to the FTIR data, the disappearance of functional groups at $1584 \mathrm{~cm}^{-1}$ for $-\mathrm{N}=\mathrm{N}-$ stretching vibrations and at $1450-1200 \mathrm{~cm}^{-1}$ for phenolic C-O stretching vibrations in the bacteria-treated water sample indicated biodegradation of $C R$ by reductive cleavage of azo bonds (Figure 4A), as previously studied [8,10]. $\mathrm{Ng}$ et al. [27] reported a similar study on CR degradation by S. xiamenensis BC01, but the absence of aromatic stretch was not demonstrated clearly in the treated sample. However, in this study, the absence of $645-831 \mathrm{~cm}^{-1}$ stretching vibration for aromatic amine in the treated water sample proved the degradation of $\mathrm{CR}$ without forming harmful secondary pollutants. Biodegradable intermediates were analysed from MS and ${ }^{1} \mathrm{HNMR}$. Further comparing this analytical result in a chemically integrative way allowed us to propose a CR biodegradation pathway (Figure 6). Possibly the first intermediate sodium 4-amino-3-(phenyldiazenyl) naphthalene2-sulfonate was formed from symmetrical cleavage on the chemical structure of $C R$, making the molecule accessible to the active site of the enzymes for further degradation reaction. Then, sodium 3,4-diaminonapthalene-2-sulfonate was formed by reductive cleavage of azo bond. The significant disappearance of azo peaks from the FTIR spectrum of the decolourised sample also supported this reaction step. As no significant ${ }^{1} \mathrm{H}$ NMR peak of product with larger molecular weight was been found in this study, it may be hypothesised that the intermediates of the biodegraded CR are probably mineralised immediately after formation and utilised by the bacterium though the TCA cycle in their central metabolism as carbon or nitrogen sources. This could be supported by the previous work of D'Souza et al. [45] on CR biodegradation by Alcaligenes sp., where similar intermediates such as the intermediates $2 \mathrm{a}$ and $3 \mathrm{a}$ from our study were also formed. It was previously found by Lade et al. [10] that azo reductase is responsible for reductive cleavage of the azo bond. The intermediate is presumed to be further cleaved to form low molecular weight aniline followed by toluene (Figure 6). From a similar study previously performed by Balapure et al. [32] on reactive black 1 using a mixed bacterial consortium of Lysinibacillus, Raoultella, Enterococcus, and Citrobacter species, it can be said that the degradation of CR probably goes through a complete mineralization mechanism. Perhaps bacteria growing in wastewater containing azo dye use complex dyes as their carbon or nitrogen sources [46] by breaking them down with the help of a complex oxido-reductive enzymatic system. In this study, probably at the time of acclimatization in the CR-containing medium, that enzymatic system helped the bacterium to degrade the dye. The azo bond of CR might be reductively cleaved to form enough carbon and nitrogen compounds for the bacterium to consume as nutrient sources.

Untreated textile wastewater presents hazards when discharged into environmental sinks (water bodies) utilised for irrigation purpose [47], making it essential to discuss the risks associated with the treated water with high ecological consequences. In a previous report, Ponceau $4 \mathrm{R}$ showed acute toxicity to Triticum aestivum L. (69\% germination rate on treatment with decolourised sample) and Sorghum vulgare L. [47]. Shoot growth was earlier reported to be inhibited in Methyl orange contamination [48]. In comparison, our results show that plants grown in CR aqueous solution probably faced a direct impact from azo dye molecules in terms of germination inhibition, seedling health, and affected shoot-root elongation, whereas toxicity of the dye was substantially reduced after bacterial biodegradation (Table 1). In a previous study by Telke et al. [49], phytotoxicity assessment 
revealed that textile effluent had a detrimental effect on seed germination of Vigna radiata $(20 \%)$ compared to the treated sample $(60 \%)$ and distilled water $(70 \%)$. Therefore, similar observations in our study confirmed that biodegraded products of CR (bacteria-degraded water) were non-toxic and showed no negative influence on seed germination or seedling growth. In a recent study by Kishor et al. [43], similar effects were observed on seed germination and seedling growth parameters of Phaseolus mungo L., showing significant reduction in the toxicity of treated textile wastewater. The bacteria-degraded intermediates might be used as a source of water or plant growth nutrients for vegetation in the near future. Findings of the statistical study, i.e., principal component analysis (Figure 8) on plant germination indexes, clearly demonstrated a distant relationship between the effects of the CR solution and those of the control and bacteria-degraded water samples. This clearly indicates that $C$. geocarposphaerae DD3 is not only able to decolourise CR but also able to completely detoxify it, resulting in almost zero or insignificant phytotoxicity.

\section{Conclusions}

Textile dye effluent origin thermotolerant bacterium C. geocarposphaerae DD3 was studied for its ability to decolourise $\mathrm{CR}$, followed by degradation and detoxification of $\mathrm{CR}$ by the bacterium. With an MTC of $0.5 \mathrm{~g} \mathrm{~L}^{-1} \mathrm{CR}, \mathrm{C}$. geocarposphaerae DD3 showed the highest decolourisation efficiency of $96.52 \%$ in the presence of glucose as co-substrate within only $12 \mathrm{~h}$ of treatment. Based upon biodegradation analysis of CR, the process seemed to involve a complete biodegradation without forming aromatic amines as secondary pollutants. Intermediates formed after biodegradation of CR exhibited no phytotoxicity toward the germination and growth of mung bean. This biodegradation and detoxification of azo dye by C. geocarposphaerae DD3 is a novel approach that could lead to a sustainable bioremediation method for dye-containing wastewater treatment in the near future. In conclusion, dye effluent origin, thermotolerant $C$. geocarposphaerae DD3 degraded and detoxified recalcitrant $\mathrm{CR}$ in a cost-effective manner, and the recycled water could be used in the future for agricultural/irrigation purposes. This study focused on efficient bioresource utilization and future opportunities for the circular bioeconomy.

Supplementary Materials: The following are available online at https:/ /www.mdpi.com/article/10 .3390 / su131910850/s1, Figure S1: Box plot representing the decolourisation percentage by statistically significant variables for DD3 mediated Congo red decolourisation. Table S1: Physico-chemical parameters of the textile effluent from collection site. Table S2: Physio-chemical characterization of bacterial isolates.

Author Contributions: Conceptualization, R.B.; formal analysis, S.S. and A.E.-V.; writing-original draft preparation, S.S.; writing-review and editing, R.B., A.B. and A.E.-V.; supervision, R.B. All authors have read and agreed to the published version of the manuscript.

Funding: This research received no external funding.

Institutional Review Board Statement: Not applicable.

Informed Consent Statement: Not applicable.

Data Availability Statement: The data presented in this study are available on request from the corresponding author.

Acknowledgments: Authors are thankful to UGC-Center of Advanced Study, Department of Botany, The University of Burdwan for pursuing research activities. S.S. and R.B. are thankful to DST-FIST (No. SR/FST/LS-1/2018/188(C) for infrastructural facilities. Authors are also thankful to Rajarshi Ghosh, Assistant Professor, Department of Chemistry, The University of Burdwan for his kind help in the analysis of data. S.S. is thankful to Swami Vivekananda Merit-Cum-Means Non Net fellowship (WBP191579671079) for pursuing PhD. All authors are also thankful to Biorender.com.

Conflicts of Interest: The authors declare no conflict of interest. 


\section{References}

1. Sarkar, S.; Ponce, N.T.; Banerjee, A.; Bandopadhyay, R.; Rajendran, S.; Lichtfouse, E. Green polymeric nanomaterials for the photocatalytic degradation of dyes: A review. Environ. Chem. Lett. 2020, 18, 1569-1580. [CrossRef]

2. Agha, Y.Y.; Bahjat, S.A.; Thanoon, M.F. Assessment of Bacterial Pigments as Textile Colorants. Indian J. Public Health Res. Dev. 2019, 10, 1565-1569. [CrossRef]

3. Carneiro, P.A.; Umbuzeiro, G.A.; Oliveira, D.P.; Zanoni, M.V.B. Assessment of water contamination caused by a mutagenic textile effluent/dyehouse effluent bearing disperse dyes. J. Hazard. Mater. 2010, 174, 694-699. [CrossRef] [PubMed]

4. Baban, A.; Yediler, A.; Lienert, D.; Kemerdere, N.; Kettrup, A. Ozonation of high strength segregated effluents from a woollen textile dyeing and finishing plant. Dye. Pigment. 2003, 58, 93-98. [CrossRef]

5. Sudha, M.; Saranya, A.; Selvakumar, G.; Sivakumar, N. Microbial degradation of azo dyes: A review. Int. J. Curr. Microbiol. Appl. Sci. 2014, 3, 670-690.

6. Tkaczyk, A.; Mitrowska, K.; Posyniak, A. Synthetic organic dyes as contaminants of the aquatic environment and their implications for ecosystems: A review. Sci. Total Environ. 2020, 717, 137222. [CrossRef] [PubMed]

7. Yaseen, D.A.; Scholz, M. Textile dye wastewater characteristics and constituents of synthetic effluents: A critical review. Int. J. Environ. Sci. Technol. 2019, 16, 1193-1226. [CrossRef]

8. Mishra, S.; Nayak, J.K.; Maiti, A. Bacteria-mediated bio-degradation of reactive azo dyes coupled with bio-energy generation from model wastewater. Clean Technol. Environ. Policy 2020, 22, 651-667. [CrossRef]

9. Singh, R.L.; Singh, P.K.; Singh, R.P. Enzymatic decolorization and degradation of azo dyes-A review. Int. Biodeterior. Biodegrad. 2015, 104, 21-31. [CrossRef]

10. Lade, H.; Govindwar, S.; Paul, D. Low-cost biodegradation and detoxification of textile azo dye CI reactive blue 172 by Providencia rettgeri strain HSL1. J. Chem. 2015, 2015, 894109. [CrossRef]

11. Solís, M.; Solís, A.; Pérez, H.I.; Manjarrez, N.; Flores, M. Microbial decolouration of azo dyes: A review. Process Biochem. 2012, 47, 1723-1748. [CrossRef]

12. Ito, T.; Adachi, Y.; Yamanashi, Y.; Shimada, Y. Long-term natural remediation process in textile dye-polluted river sediment driven by bacterial community changes. Water Res. 2016, 100, 458-465. [CrossRef]

13. Yu, J.; Wang, X.; Yue, P.L. Optimal decolorization and kinetic modeling of synthetic dyes by Pseudomonas strains. Water Res. 2001, 35, 3579-3586. [CrossRef]

14. Paul, S.A.; Chavan, S.K.; Khambe, S.D. Studies on characterization of textile industrial waste water in Solapur city. Int. J. Chem. Sci. 2012, 10, 635-642.

15. Guadie, A.; Tizazu, S.; Melese, M.; Guo, W.; Ngo, H.H.; Xia, S. Biodecolorization of textile azo dye using Bacillus sp. strain CH12 isolated from alkaline lake. Biotechnol. Rep. 2017, 15, 92-100. [CrossRef] [PubMed]

16. Yaseen, D.A.; Scholz, M. Shallow pond systems planted with Lemna minor treating azo dyes. Ecol. Eng. 2016, 94, 295-305. [CrossRef]

17. Sekomo, C.B.; Rousseau, D.P.; Saleh, S.A.; Lens, P.N. Heavy metal removal in duckweed and algae ponds as a polishing step for textile wastewater treatment. Ecol. Eng. 2012, 44, 102-110. [CrossRef]

18. Shah, A.H.; Manikandan, E.; Ahmed, M.B.; Ganesan, V. Enhanced bioactivity of Ag/ZnO nanorods-A comparative antibacterial study. J. Nanomed. Nanotechol. 2013, 4, 3. [CrossRef]

19. Sarkar, S.; Banerjee, A.; Halder, U.; Biswas, R.; Bandopadhyay, R. Degradation of synthetic azo dyes of textile industry: A sustainable approach using microbial enzymes. Water Conserv. Sci. Eng. 2017, 2, 121-131. [CrossRef]

20. Zerva, I.; Remmas, N.; Kagalou, I.; Melidis, P.; Ariantsi, M.; Sylaios, G.; Ntougias, S. Effect of Chlorination on Microbiological Quality of Effluent of a Full-Scale Wastewater Treatment Plant. Life 2021, 11, 68. [CrossRef]

21. Wuhrmann, K.; Mechsner, K.L.; Kappeler, T.H. Investigation on rate-Determining factors in the microbial reduction of azo dyes. Appl. Microbiol. Biotechnol. 1980, 9, 325-338. [CrossRef]

22. Dave, S.R.; Patel, T.L.; Tipre, D.R. Bacterial Degradation of Azo Dye Containing Wastes. In Microbial Degradation of Synthetic Dyes in Wastewaters; Singh, S., Ed.; Springer: Cham, Switzerland, 2015; pp. 57-83. [CrossRef]

23. Manjarrez Paba, G.; Baldiris Ávila, R.; Baena Baldiris, D. Application of environmental bacteria as potential methods of azo dye degradation systems. Glob. J. Environ. Sci. Manag. 2021, 7, 131-154. [CrossRef]

24. Gharbani, P.; Tabatabaii, S.M.; Mehrizad, A. Removal of Congo red from textile wastewater by ozonation. Int. J. Environ. Sci. Technol. 2008, 5, 495-500. [CrossRef]

25. Gopinath, K.P.; Murugesan, S.; Abraham, J.; Muthukumar, K. Bacillus sp. mutant for improved biodegradation of Congo red: Random mutagenesis approach. Bioresour. Technol. 2009, 100, 6295-6300. [CrossRef]

26. Hsueh, C.C.; Chen, B.Y. Comparative study on reaction selectivity of azo dye decolorization by Pseudomonas luteola. J. Hazard. Mater. 2007, 141, 842-849. [CrossRef] [PubMed]

27. Ng, I.S.; Chen, T.; Lin, R.; Zhang, X.; Ni, C.; Sun, D. Decolorization of textile azo dye and Congo red by an isolated strain of the dissimilatory manganese-reducing bacterium Shewanella xiamenensis BC01. Appl. Microbiol. Biotechnol. 2014, 98, 2297-2308. [CrossRef] [PubMed]

28. Nishioka, T.; Elsharkawy, M.M.; Suga, H.; Kageyama, K.; Hyakumachi, M.; Shimizu, M. Development of culture medium for the isolation of Flavobacterium and Chryseobacterium from rhizosphere soil. Microbes Environ. 2016, 31, ME15144. [CrossRef] [PubMed] 
29. American Public Health Association. Standard Methods Barrfor the Examination of Water and Waste Water, 20th ed.; American Public Health Association: Washington, DC, USA, 1998.

30. Pelczar, M.J.; Bard, R.C.; Burnett, G.W.; Conn, H.J.; Demoss, R.D.; Euans, E.E.; Weiss, F.A.; Jennison, M.W.; Meckee, A.P.; Riker, A.J.; et al. Manual of Microbiological Methods. In Society of American Bacteriology; McGraw Hill: New York, NY, USA, 1957.

31. Rana, S.; Kumar, K. Study of Phytotoxic effect of textile wastewater on seed germination and seedling growth of Triticum aestivum. Int. J. Biosci. Technol. 2017, 10, 58-66.

32. Balapure, K.; Aghera, P.; Bhatt, N.; Madamwar, D. Community synergism: Degradation of triazine dye reactive black 1 by mixed bacterial cultures KND_PR under microaerophilic and aerobic conditions. Environ. Process. 2019, 6, 713-739. [CrossRef]

33. Mishra, S.; Mohanty, P.; Maiti, A. Bacterial mediated bio-decolourization of wastewater containing mixed reactive dyes using jack-fruit seed as co-substrate: Process optimization. J. Clean. Prod. 2019, 235, 21-33. [CrossRef]

34. You, R.; Domínguez, C.; Matamoros, V.; Bayona, J.M.; Díez, S. Chemical characterization and phytotoxicity assessment of peri-urban soils using seed germination and root elongation tests. Environ. Sci. Pollut. R. 2019, 26, 34401-34411. [CrossRef]

35. Nachiyar, C.V.; Rajkumar, G.S. Degradation of a tannery and textile dye, Navitan Fast Blue S5R by Pseudomonas aeruginosa. World J. Microbiol. Biotechnol. 2003, 19, 609-614. [CrossRef]

36. Kolekar, Y.M.; Pawar, S.P.; Gawai, K.R.; Lokhande, P.D.; Shouche, Y.S.; Kodam, K.M. Decolorization and degradation of Disperse Blue 79 and Acid Orange 10, by Bacillus fusiformis KMK5 isolated from the textile dye contaminated soil. Bioresour. Technol. 2008, 99, 8999-9003. [CrossRef] [PubMed]

37. Hamad, M.T.; Saied, M.S. Kinetic studies of Congo red dye adsorption by immobilized Aspergillus niger on alginate. Appl. Water Sci. 2021, 11, 35. [CrossRef]

38. Kapdan, I.K.; Kargia, F.; McMullan, G.; Marchant, R. Effect of environmental conditions on biological decolorization of textile dyestuff by C. versicolor. Enzyme Microb. Technol. 2000, 26, 381-387. [CrossRef]

39. Chen, K.C.; Wu, J.Y.; Liou, D.J.; Hwang, S.C.J. Decolorization of the textile dyes by newly isolated bacterial strains. J. Biotechnol. 2003, 101, 57-68. [CrossRef]

40. Asad, S.; Amoozegar, M.A.; Pourbabaee, A.; Sarbolouki, M.N.; Dastgheib, S.M.M. Decolorization of textile azo dyes by newly isolated halophilic and halotolerant bacteria. Bioresour. Technol. 2007, 98, 2082-2088. [CrossRef] [PubMed]

41. Singh, R.P.; Singh, P.K.; Singh, R.L. Bacterial Decolorization of Textile Azo Dye Acid Orange by Staphylococcus hominis RMLRT03. Toxicol. Int. 2014, 21, 160-166. [CrossRef]

42. Sari, I.P.; Simarani, K. Decolorization of selected azo dye by Lysinibacillus fusiformis W1B6: Biodegradation optimization, isotherm, and kinetic study biosorption mechanism. Adsorpt. Sci. Technol. 2019, 37, 492-508. [CrossRef]

43. Kishor, R.; Purchase, D.; Saratale, G.D.; Ferreira, L.F.R.; Bilal, M.; Iqbal, H.M.; Bharagava, R.N. Environment friendly degradation and detoxification of Congo red dye and textile industry wastewater by a newly isolated Bacillus cohnni (RKS9). Environ. Technol. Innov. 2021, 22, 101425. [CrossRef]

44. Asses, N.; Ayed, L.; Hkiri, N.; Hamdi, M. Congo red decolorization and detoxification by Aspergillus niger: Removal mechanisms and dye degradation pathway. BioMed Res. Int. 2018, 2018, 3049686. [CrossRef]

45. D'Souza, E.; Fulke, A.B.; Mulani, N.; Ram, A.; Asodekar, M.; Narkhede, N.; Gajbhiye, S.N. Decolorization of Congo red mediated by marine Alcaligenes species isolated from Indian West coast sediments. Environ. Earth Sci. 2017, 76, 721. [CrossRef]

46. Barragán, B.E.; Costa, C.; Marquez, M.C. Biodegradation of azo dyes by bacteria inoculated on solid media. Dye. Pigment. 2007, 75, 73-81. [CrossRef]

47. Masarbo, R.S.; Niranjana, S.R.; Monisha, T.R.; Nayak, A.S.; Karegoudar, T.B. Efficient decolorization and detoxification of sulphonated azo dye Ponceau $4 \mathrm{R}$ by using single and mixed bacterial consortia. Biocatal. Biotransform. 2019, 37, 367-376. [CrossRef]

48. Haque, M.M.; Haque, M.A.; Mosharaf, M.K.; Marcus, P.K. Decolorization, degradation and detoxification of carcinogenic sulfonated azo dye methyl orange by newly developed biofilm consortia. Saudi J. Biol. Sci. 2021, 28, 793-804. [CrossRef] [PubMed]

49. Telke, A.A.; Joshi, S.M.; Jadhav, S.U.; Tamboli, D.P.; Govindwar, S.P. Decolorization and detoxification of Congo red and textile industry effluent by an isolated bacterium Pseudomonas sp. SU-EBT. Biodegradation 2010, 21, 283-296. [CrossRef] 